\title{
Effect of diet energy level and genomic residual feed intake on bred Holstein dairy heifer growth and feed efficiency
}

\author{
K. T. Williams, ${ }^{1} \odot$ K. A. Weigel, ${ }^{1} \odot$ W. K. Coblentz, ${ }^{2} \odot$ N. M. Esser, ${ }^{3} \odot$ H. Schlesser, ${ }^{4}$ P. C. Hoffman,,${ }^{1,5}$ \\ R. Ogden, ${ }^{2}$ (1) H. Su, ${ }^{6}$ (b) and M. S. Akins ${ }^{1 *}$ (1) \\ ${ }^{1}$ Department of Animal and Dairy Sciences, University of Wisconsin-Madison, Madison 53706 \\ ${ }^{2}$ USDA Dairy Forage Research Center, Marshfield, WI 54449 \\ ${ }^{3}$ Marshfield Agricultural Research Station, University of Wisconsin-Madison, Marshfield 54449 \\ ${ }^{4}$ Marathon County Extension, University of Wisconsin-Madison, Wausau 54403 \\ ${ }^{5}$ Vita Plus Corporation, Madison, WI 53713 \\ ${ }^{6}$ Department of Animal Nutrition and Feed Science, China Agricultural University, Beijing, China 100193
}

\begin{abstract}
The objective of this study was to determine growth, feed intake, and feed efficiency of postbred dairy heifers with different genomic residual feed intake (RFI) predicted as a lactating cow when offered diets differing in energy density. Postbred Holstein heifers $(\mathrm{n}=128$, ages $14-20 \mathrm{mo}$ ) were blocked by initial weight (high, medium-high, medium-low, and low) with 32 heifers per block. Each weight block was sorted by RFI (high or low) to obtain 2 pens of heifers with high and low genomically predicted RFI within each block ( 8 heifers per pen). Low RFI heifers were expected to have greater feed efficiency than high RFI heifers. Dietary treatments consisted of a higher energy control diet based on corn silage and alfalfa haylage [HE; $62.7 \%$ total digestible nutrients, $11.8 \%$ crude protein, and $45.6 \%$ neutral detergent fiber; dry matter (DM) basis], and a lower energy diet diluted with straw (LE; $57.0 \%$ total digestible nutrients, $11.7 \%$ crude protein, and $50.1 \%$ neutral detergent fiber; DM basis). Each pen within a block was randomly allocated a diet treatment to obtain a $2 \times 2$ factorial arrangement ( 2 RFI levels and 2 dietary energy levels). Diets were offered in a 120-d trial. Dry matter intake by heifers was affected by diet (11.0 vs. $10.0 \mathrm{~kg} / \mathrm{d}$ for $\mathrm{HE}$ and LE, respectively) but not by RFI or the interaction of RFI and diet. Daily gain was affected by the interaction of RFI and diet, with low RFI heifers gaining more than high RFI heifers when fed LE (0.94 vs. $0.85 \mathrm{~kg} / \mathrm{d}$ for low and high RFI, respectively), but no difference for RFI groups when fed HE (1.16 vs. $1.19 \mathrm{~kg} / \mathrm{d}$ for low and high RFI, respectively). Respective feed efficiencies were improved
\end{abstract}

Received December 1, 2020.

Accepted November 8, 2021.

*Corresponding author: msakins@wisc.edu for low RFI compared with high RFI heifers when fed LE (10.6 vs. $11.8 \mathrm{~kg}$ of feed $\mathrm{DM} / \mathrm{kg}$ of gain), but no effect of RFI was found when fed HE (9.4 vs. $9.5 \mathrm{~kg}$ of $\mathrm{DM} / \mathrm{kg}$ of gain for high and low RFI, respectively). No effect of RFI or diet on first-lactation performance through 150 DIM was observed. Based on these results, the feed efficiency of heifers having different genomic RFI may be dependent on diet energy level, whereby low RFI heifers utilized the LE diet more efficiently. The higher fiber straw (LE) diet controlled intake and maintained more desirable heifer weight gains. This suggests that selection for improved RFI in lactating cows may improve feed efficiency in growing heifers when fed to meet growth goals of 0.9 to $1.0 \mathrm{~kg}$ of gain/d.

Key words: dairy heifer, residual feed intake, diet energy

\section{INTRODUCTION}

Much emphasis has been placed on replacement heifer nutrition programs with the goal of establishing an ideal program to rear heifers at a minimal cost without compromising growth, pregnancy, and future lactation performance. Research has honed in on 2 feeding strategies to reach these goals, (1) limit-feeding and (2) diet dilution, to fulfill heifer nutrient requirements, potentially reduce costs, and prevent over-conditioning.

Limit-feeding is a management practice that limits the feed intake of a more nutrient-dense diet to control nutrient intake and growth, as well as improve efficiency. Such programs, although proven successful, can have behavioral drawbacks including (1) increased standing without eating (Hoffman et al., 2007; Greter et al., 2011), (2) increased reaching for feed that is inaccessible, and (3) increased vocalization (Hoffman et al., 2007). This system relies on a high level of nutritional management and proper facility design that can be challenging within some operations. 
Dietary dilution is another management practice that has proven successful in reducing caloric intake by substituting a higher fiber, lower digestibility forage such as straw, warm-season perennial grasses, lowquality hay, sorghum forages, or corn stover for some of the high-quality forages (primarily corn silage and alfalfa silage) when offered at ad libitum intakes (Coblentz et al., 2012; Su et al., 2017; Li et al., 2019b). Using this feeding practice, dairy producers are able to potentially reduce feed costs by controlling feed intakes, utilize lower-cost forages, and provide heifers with opportunities to express natural foraging behavior (Greter et al., 2008). Use of higher fiber diets to control intake is based on heifers having the capacity to eat approximately $1 \%$ of BW in NDF each day (Hoffman et al., 2008). Thus, DMI can be predicted if the diet NDF content is known and nutrient composition balanced to meet nutrient needs. Ad libitum feeding of a diluted diet may serve as a useful management practice because it allows producers to control growth rates and potentially reduce feed costs if facilities or management are not able to facilitate a limit-feeding program.

Feed costs account for a large proportion of expenses for dairy production (Vallimont et al., 2011), with heifer feeding costs being approximately half of the total heifer rearing costs after weaning (Akins et al., 2015). To improve income over feed cost, genomic selection for animals that are more feed efficient may be useful to produce similar milk yields or growth with less feed. Residual feed intake (RFI) is the difference between an animal's actual energy intake and its expected energy intake based on the animal's maintenance requirements and production level, and is phenotypically independent of production and body size (Koch et al., 1963). Animals are considered to be more efficient if they consume less feed than expected without suppressing production when compared with other animals in the same cohort. These animals will have a negative RFI value, whereas animals that are considered less efficient will possess a positive RFI value. Measurement of RFI for lactating cows involves measurement of feed intake, milk production and composition, and $\mathrm{BW}$ gain or loss to provide information on energy intake as feed and energy output or storage as milk, maintenance, and weight gain or loss. Thus, RFI is difficult to measure on a large scale compared with other measures (milk yield and composition), so the use of genomics to predict RFI based on an animal's genetics is a potential option for selection. Genomic prediction of RFI first involves collecting actual RFI data and genomic SNP markers from a reference population to formulate a genomic prediction model. To make genomic predictions of RFI, SNP marker data from cattle with unknown RFI are then entered into the prediction model. Use of genomic selec- tion to improve efficiency of consumed dietary energy in lactating cows has become a key priority in dairy cattle improvement programs worldwide with studies comparing actual RFI with genomic predictions of RFI in cows (Berry et al., 2014; de Haas et al., 2015) and heifers (Pryce et al., 2012, 2015). There is evidence that dairy heifers have variation in actual RFI (Williams et al., 2011) with the $10 \%$ most efficient heifers (250 d of age) eating $1.7 \mathrm{~kg} / \mathrm{d}$ less for a similar rate of gain than the $10 \%$ least efficient of heifers. However, there is limited research relating the genomically predicted RFI as a lactating cow with actual feed efficiency as a growing heifer. A previous study (Williams et al., 2019) with prebreeding dairy heifers showed minimal effects of RFI on growth or feed efficiency; however, this has not been investigated in bred or pregnant heifers, which have greater intakes, similar growth, and lower efficiency.

The objective of this study was to determine the effect of dietary energy level and genomic RFI on postbred dairy heifer performance that primarily focuses on growth, feed intake, feed efficiency, and subsequent first-lactation production. We hypothesized that heifers fed a higher fiber, lower energy diet would have lower feed intake and more optimal growth than heifers fed a higher energy diet. Also, we hypothesized that heifers with a lower genomically predicted RFI as a cow would have improved feed efficiency as a heifer.

\section{MATERIALS AND METHODS}

\section{Animals, Housing, and Diets}

All animal handling procedures for this experiment were approved by the Research Animal Resources Committee of the University of Wisconsin-Madison (protocol \#A005117). One hundred twenty-eight postbred (ages 14-20 mo) Holstein heifers were stratified into 4 blocks (32 heifers/block) by initial BW (mean $\pm \mathrm{SD}$; low, $400 \pm 8.8 \mathrm{~kg}$; medium-low, $443 \pm 6.6 \mathrm{~kg}$; mediumhigh, $473 \pm 3.5 \mathrm{~kg}$; or high, $510 \pm 7.3 \mathrm{~kg}$ ). Heifers were bred according to herd standard procedures with first breeding when heifers are at least $375 \mathrm{~kg}$ of BW and 13 mo of age, with the days in gestation not controlled for across treatments. The mean and standard deviation days in gestation at the start of the study for the 4 weight blocks were $20.3 \pm 24.2 \mathrm{~d}$ for low, $47.8 \pm 33.7$ $\mathrm{d}$ for medium-low, $59.7 \pm 41.8 \mathrm{~d}$ for medium-high, and $73.8 \pm 42.4 \mathrm{~d}$ for high. Within each weight block there were 4 identical research pens, each containing 8 heifers randomly assigned from the weight block; therefore, a total of 16 pens were included in the study. Within each weight block, heifers were further allocated into low genomic RFI (LRFI; $\mathrm{n}=16 /$ block) and high genomic RFI (HRFI; $\mathrm{n}=16 /$ block) heifers, which were 
predicted to be more and less efficient, respectively, based on their predicted performance as lactating cows. The LRFI heifer pens had a mean genomic RFI difference of $-0.138 \pm 0.092 \mathrm{~kg} / \mathrm{d}$ of $\mathrm{DM}$ from predicted intake, with the mean pen minimum and maximum being -0.290 and -0.017 , respectively. The HRFI heifer pens had a mean genomic RFI difference of $0.115 \pm$ $0.082 \mathrm{~kg} / \mathrm{d}$ of DM from predicted intake, with the mean pen minimum and maximum being 0.004 and 0.267 , respectively. Overall individual-animal mean genomic RFI difference across all animals in the study was $-0.010 \pm 0.157 \mathrm{~kg}$ of DM from predicted intakes, with a range of -0.364 to 0.338 . Additional information on determination of genomic RFI is provided later in the experimental methods.

Diets with differing energy content [higher energy $\operatorname{diet}(\mathbf{H E})$ or lower energy diet diluted with straw $(\mathbf{L E})$ ] comprised the other aspect of the treatment structure, with each RFI treatment pen randomized to either HE or LE diets, resulting in a 2 (RFI levels) $\times 2$ (dietary energy densities) factorial arrangement of treatments, in which pen served as the experimental unit (StPierre, 2007) with 4 pens per treatment combination. The sample size of 4 pens/treatment was determined using previous pen-based heifer growth data from the research facility with a mean ADG of $1.0 \mathrm{~kg}$, standard deviation of $0.1 \mathrm{~kg}$ of $\mathrm{ADG}$, expected treatment difference of $0.2 \mathrm{~kg}$ of ADG, an $\alpha$-error level of 0.05 , and $80 \%$ power $(1-\beta)$ level. All staff on the research team and at the research facility were aware of treatment allocations during the study with no blinding of treatments.

Animals were housed at the University of Wisconsin Marshfield Agricultural Research Station (Stratford, WI). Heifers were housed in 16 identical research pens that contained continuous access to fresh water, an automated mechanical alley-scraping system, 8 freestalls with foam-core mattresses bedded with a shallow layer of dried organic solids, and 8 head-locking gates that remained unlocked during the study to allow ad libitum feeding of TMR. Diets were delivered as TMR between 0900 and $1100 \mathrm{~h}$ every day, and feed was pushed up within easy reach of the heifers using a blade affixed to a small tractor at least twice daily. Animals were monitored at least 3 times daily for signs of disease, stress, or pain with no animals needing to be removed during the heifer feeding research period.

Heifers were offered 1 of 2 treatment diets: (1) HE, which contained $48.0 \%$ corn silage and $52.0 \%$ alfalfa silage, and (2) LE, which contained $26.8 \%$ corn silage, $59.1 \%$ alfalfa silage, and $14.1 \%$ wheat straw. A mineral supplement (described in Table 1) was added to the diets at a set amount per heifer $(122 \mathrm{~g} / \mathrm{d})$ to minimize variation in mineral intakes across diet treatments. Diets remained iso-nitrogenous (overall mean $=11.8 \%$ ) with a reduction in caloric density of 5.7 percentage units of TDN for the LE diet (57.0\% TDN, DM basis) relative to $\mathrm{HE}$ (62.7\% TDN, DM basis). Diets were formulated to provide $58 \%$ TDN for LE and $63 \%$ TDN for HE to determine effects of additional energy supply. These formulations resulted in a reduction of $\mathrm{ME}$ for the $\mathrm{LE}(2.18 \mathrm{Mcal}$ of $\mathrm{ME} / \mathrm{kg}$ of $\mathrm{DM})$ diet relative to the $\mathrm{HE}$ diet $(2.39 \mathrm{Mcal}$ of $\mathrm{ME} / \mathrm{kg}$ of $\mathrm{DM})$. Diets were formulated for daily gains of $0.85 \mathrm{~kg} / \mathrm{d}$ for heifers fed $\mathrm{LE}$ and $1.15 \mathrm{~kg} / \mathrm{d}$ for heifers fed HE, with heifer BW and day in gestation of $475 \mathrm{~kg}$ and $60 \mathrm{~d}$ in gestation, respectively. Feed intakes were predicted based on heifers consuming $1 \%$ of BW daily as NDF (Hoffman et al., 2008). Average daily gain goals for LE were set for optimal gains, whereas goals for the HE diet were above the optimal range. The optimal daily gain was based on heifer starting age and weight, a mature weight of lactating cows in the research herd, and a goal of first breeding by 13 mo of age. Furthermore, these markers should allow attainment of a desired goal of first calving between 22 and 24 mo of age. Diets were offered ad libitum for $120 \mathrm{~d}$ with daily TMR allocations adjusted to maintain a bunk score of 1 (2-3\% refusals), where $0=$ no feed particles remaining, $1=$ only scattered feed particles remaining, 2 = numerous particles remaining, but concrete floor is still easily visible, or $3=$ feed particles completely covering the concrete bunk floor (Hoffman et al., 2008). Orts were collected daily at $0830 \mathrm{~h}$ from each pen, weighed in a tared plastic bin, subsampled, and frozen $\left(-20^{\circ} \mathrm{C}\right)$ for future analysis. Each TMR was sampled daily at feed delivery and kept frozen $\left(-20^{\circ} \mathrm{C}\right)$ for future analysis. Individual feed component samples were collected once weekly and kept frozen $\left(-20^{\circ} \mathrm{C}\right)$ for future analysis. Ingredient and nutrient compositions of the treatment diets and individual dietary components are presented in Table 1.

\section{Genomic Residual Feed Intake}

Genomic predictions for RFI as a lactating cow were computed for the heifers in this study using 60,671 SNP markers throughout the genome with genomic BLUP. The reference population consisted of 3,522 Holstein cows at 10 research stations throughout the United States and Canada; these cows had individual DMI, milk yield, milk composition, BW, and BCS data recorded daily over a minimum of $28 \mathrm{~d}$, during the period from 50 to $200 \mathrm{~d}$ postpartum (Tempelman et al., 2015). Phenotypes for RFI of the cows in the reference population were calculated as the difference between consumed DMI $(\mathrm{kg} / \mathrm{d})$ and expected DMI, where the expectation for a given cow is based on her secreted milk energy, metabolic BW, and BW change relative to other cows in her experimental cohort. Cows in the ref- 
erence population had data regarding SNP genotypes and RFI phenotypes, whereas heifers in this study had SNP genotypes only, with RFI phenotypes treated as missing while predicting their genomic breeding values for RFI based on their genomic similarity to cows in the reference population. It should be noted that the genomic prediction for RFI of a lactating cow reflects the expected increase or decrease in DMI relative to contemporary cows with similar milk yield, milk composition, body size, and body composition. This trait is different from RFI of a growing heifer, which would reflect the increase or decrease in DMI relative to contemporary heifers with similar growth rate and body size.

\section{BW, Measurements, and Ultrasounds}

Initial and final BW were taken for 3 consecutive days immediately before feeding using a cattle chute
(Real Tuff) equipped with an electronic scale (Tru-Test Inc.). Heifers were not fasted before weight and body measurements. Initial BW were taken on $\mathrm{d}-2,-1$, and 0 , whereas final BW were obtained on d 118, 119, and 120. Initial and final body measurements were assessed on 1 of the 3 weigh days, and included heart girth, body length, hip height, hip width, and BCS. Body condition scores were taken by 2 trained evaluators on a scale of 1 to 5 , where $1=$ emaciated and $5=$ obese (Wildman et al., 1982) with 0.5-unit increments used to best describe heifer body condition.

Ultrasound measurements (Aloka Echo Camera Model SSD-500 and Aloka Ultrasound Probe UST5044-3.5, Aloka Co. Ltd.) of rump fat thickness and kidney fat depth were taken on 1 of the $3 \mathrm{~d}$ during each measurement sequence. Animals were brushed clean of debris and vegetable oil was applied to the ultrasound sites as an imaging medium. Ultrasound measures were taken of the rump fat and kidney fat depth to assess

Table 1. Ingredient composition of treatment diets and mean nutrient composition of TMR and individual diet components based on weekly analysis

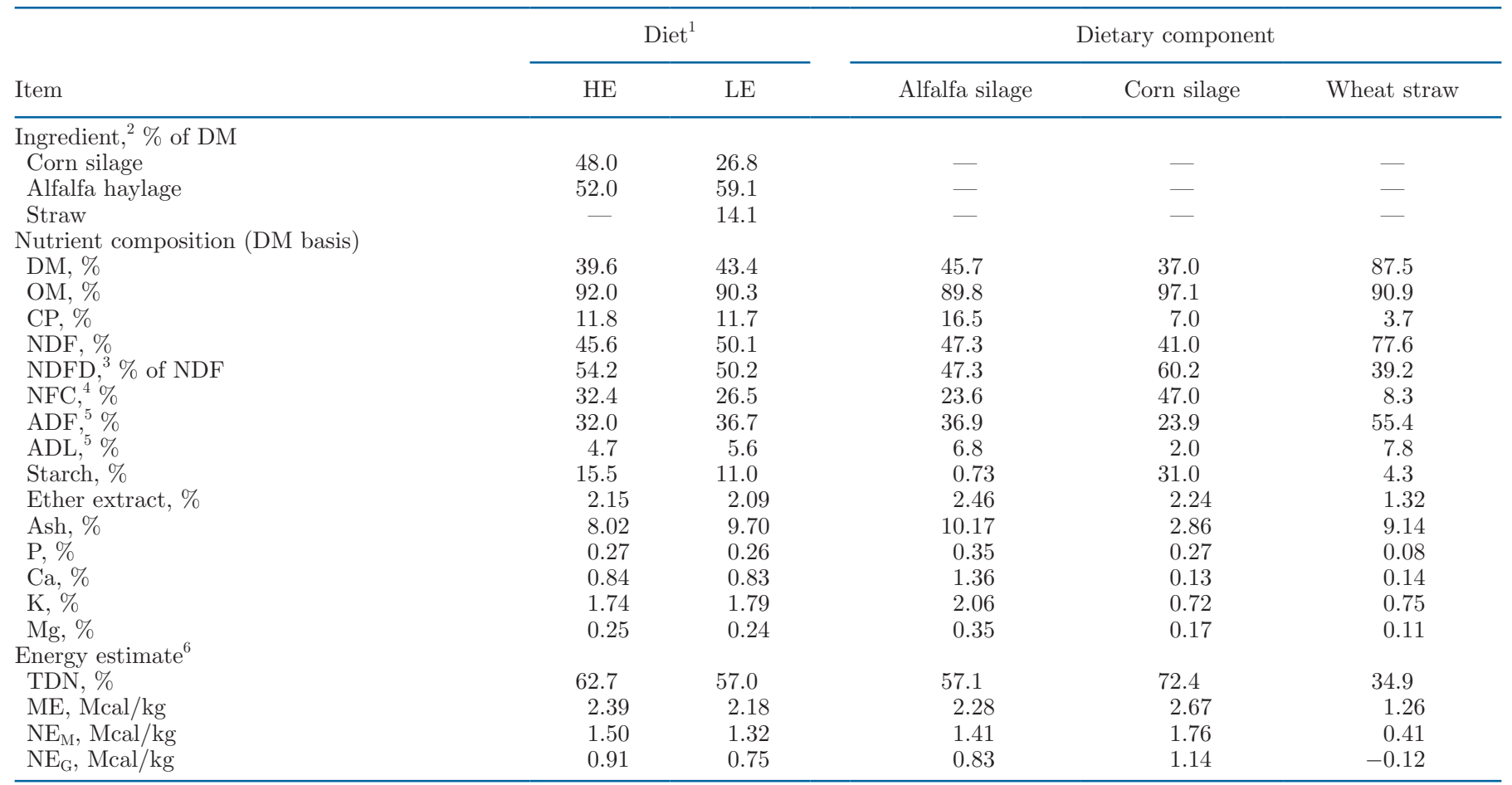

${ }^{1} \mathrm{HE}=$ diet with $52 \%$ alfalfa silage and $48 \%$ corn silage (DM basis) offered for ad libitum intake; LE = diet with $59.1 \%$ alfalfa silage, $26.8 \%$ corn silage, and $14.1 \%$ straw (DM basis) offered for ad libitum intake.

${ }^{2}$ Mineral package contained $70.7 \%$ calcium carbonate, $15.1 \%$ salt, $5.04 \%$ magnesium oxide, $2.12 \%$ sulfur, $1.62 \%$ selenium (1,600 ppm Se), $1.56 \%$ vitamin A, $0.91 \%$ manganese sulfate, $0.68 \%$ vitamin $\mathrm{E}$ ( $50 \%$ vitamin $\mathrm{E}$ ), $0.65 \%$ copper sulfate, $0.50 \%$ vitamin $\mathrm{D}, 0.50 \%$ mineral oil, $0.33 \%$ iodine $\operatorname{mix}(7.3 \% \mathrm{I}), 0.23 \%$ thiamine mononitrate (99\% thiamine), and $0.025 \%$ cobalt carbonate. Mineral package was blended into the total diet at a rate of $122 \mathrm{~g} /$ heifer per day and delivered as a TMR.

${ }^{3} \mathrm{NDF}$ digestibility determined following a 48-h digestion in buffered rumen fluid.

${ }^{4} \mathrm{NFC}=100-(\% \mathrm{NDF}+\% \mathrm{CP}+\%$ ether extract $+\%$ ash $)$.

${ }^{5}$ Concentrations of ADF and ADL were determined for wk 4, 8, 12, and 16 without preliminary digestion in neutral detergent solution; thus, ADF includes pectin.

${ }^{6}$ Calculated according to NRC (2001). 
internal body fat as a confirmation of BCS (Schröder and Staufenbiel, 2006; Ribeiro et al., 2008). The examination site for rump fat is located in the sacral region between the caudal one-quarter and one-fifth connection line going from the dorsal part of the pins to the hooks (Schröder and Staufenbiel, 2006). Rump fat is positioned between the skin and the profound fascia and appears as a white line underneath the skin. The point of measurement is underneath the layer of skin and extends to the bottom of the profound fascia. The examination site for kidney fat is located between the first lumbar and the 13th rib (Ribeiro et al., 2008). The point of measurement is taken from the bottom of the spine or rib to the bottom of the kidney fat deposit.

\section{Fecal Sampling and Whole-Pen Manure Collection}

Whole-pen manure collections were conducted during wk 8 and 16 to quantify the actual excreta DM produced within each pen during a 48-h collection period (Coblentz et al., 2013). Heifers were removed from their pens to allow for removal of bedding before the start of collection procedures. The removal of bedding prevented the need for extensive techniques to separate bedding from manure (Coblentz et al., 2013). Manure in this study is defined as only containing feces and urine, and void of waste bedding and feed. Alley-scrapers were used to clean manure from each pen before the start of the collection period, and hand-scrapers were used to remove manure from mattresses within the freestall. Alley-scrapers were removed and rubber panels placed between pens during the collection period to prevent cross-contamination of urine and manure across treatment pens (Hoffman et al., 2007). Manure was allowed to accumulate in the pens for $48 \mathrm{~h}$.

After $48 \mathrm{~h}$, animals were removed from pens and manure was collected using a skid-loader and hand shovels to ensure removal from alleys, mattresses, and panels. Manure was placed in a small $4.4-\mathrm{m}^{3}$ manure spreader (H\&S Manufacturing Company Inc.) fitted with electronic load cells (Digi-Star). The weight of contents was taken before transferring manure from the barn to a concrete slab to ensure accuracy for contents that may be lost in transit. Subsequently, all contents were unloaded onto a clean, flat concrete slab, sampled from 10 to 15 locations at various depths in the pile, and placed into 19-L plastic buckets. Samples were then mixed thoroughly, and a subsample was placed in a 3.8-L plastic storage bag and stored in a cooler over ice, pending transport to the laboratory for analysis.

Manure samples were transported to the laboratory and thoroughly mixed, and a 20-g subsample from each pen was placed in an aluminum pan and dried for $24 \mathrm{~h}$ at $100^{\circ} \mathrm{C}$ to determine concentration of DM. Subsamples were analyzed in quadruplicate and DM concentrations were averaged to determine the mean DM concentration for each pen manure sample. After $\mathrm{DM}$ analysis, samples were combusted at $500^{\circ} \mathrm{C}$ for 6 $\mathrm{h}$ in a muffle furnace to determine ash concentrations with OM concentrations calculated as 100 - ash \%. Remaining manure samples were kept frozen $-20^{\circ} \mathrm{C}$ in 3.8-L plastic bags for future nutrient analysis.

\section{Laboratory Analysis of Treatment Diets}

Individual feed components, orts, and TMR samples were thawed weekly before immediate analysis. The TMR and ort samples were composited within week by mixing samples in a large plastic 70-L tub, then subsampled to obtain a 400- to 500-g sample. Subsamples were dried to a constant weight under forced air at $55^{\circ} \mathrm{C}$, then ground through a $1-\mathrm{mm}$ screen in Wiley mill (model 4, Thomas Scientific) and stored in plastic sample bags. All TMR and ort samples were analyzed by the University of Wisconsin Soil and Forage Analysis Laboratory (Marshfield, WI) for (1) DM using AOAC procedures (AOAC, 1990); (2) CP by a macro-Kjeldahl procedure (AOAC International, 1998; method 988.05); (3) ash by combustion in a muffle furnace at $\left(500^{\circ} \mathrm{C}\right.$ ) for $6 \mathrm{~h}$; (4) starch (YSI model 2700D, Yellow Springs Instrument Co.); (5) NDF by the methods of Goering and Van Soest (1970) with both heat-stable amylase and sodium sulfite included within the NDF solution; (6) 48-h in vitro digestion of NDF (NDFD) in buffered rumen fluid using procedures described in detail by Kruse et al. (2010); (7) ether extract (AOAC, 1990; method 920.29) using equal parts anhydrous ether and petroleum ether as solvents; (8) Ca, K, and $\mathrm{Mg}$ by atomic absorption spectroscopy; and (9) P by colorimetric methodology (Schulte et al., 1987). Rumen fluid for in vitro digestion analysis was obtained from 2 nonlactating Holstein cows offered an alfalfa haylage diet $(16.7 \%$ CP, $55.6 \%$ TDN, $49.5 \%$ NDF). Samples of TMR obtained from wk 4, 8, 12, and 16 were also analyzed for ADF and ADL by the methods of Goering and Van Soest (1970) without a preliminary digestion in neutral detergent, thus the ADF data presented include pectin. Calculations of $\mathrm{TDN}, \mathrm{ME}, \mathrm{NE}_{\mathrm{G}}$, and $\mathrm{NE}_{\mathrm{M}}$ of treatment diets were made using summative equations (NRC, 2001) with 48-h NDFD serving as a digestibility coefficient for NDF to estimate truly digestible fiber.

\section{Calculation of Diet Digestibility}

Digestibilities of DM, OM, NDF, ADF, and apparent $\mathrm{N}$ of diets were determined on a whole-pen basis during 
wk 8 and 16 of the trial. Whole-pen manure samples were dried to a constant weight under forced air at $55^{\circ} \mathrm{C}$, then ground through a $1-\mathrm{mm}$ screen in Wiley mill (model 4, Thomas Scientific). Concentrations of ash in diet and ort samples from wk 8 and 16 were determined from $1.0-\mathrm{g}$ subsamples by combustion in a muffle furnace at $500^{\circ} \mathrm{C}$ for $6 \mathrm{~h}$. Total $\mathrm{N}$ was determined by a rapid combustion procedure (AOAC International, 1998; method 990.63; TruMac CN, Leco Corporation), and NDF was determined using procedures described by Ankom with heat-stable amylase and sodium sulfite included in the NDF solution (Ankom Technologies). Organic matter was calculated as 100 - ash \%. Nutrients excreted in manure were calculated by multiplying the manure DM excreted by the manure nutrient concentration. Nutrient digestibilities were calculated as $100-($ manure nutrient amount/nutrient intake $\times 100$ ) for each collection period. All calculations of nutrient digestibilities were based on DMI and orts collected over wk 8 and 16 for each pen. The mean nutrient digestibilities from wk 8 and 16 for each pen were used in the statistical analysis.

\section{Lactation Data}

All animals were off study at least 6 wk before calving, with heifers moved into the dry cow pens $60 \mathrm{~d}$ before expected calving and the actual days on the dry cow ration ranging between 42 and $60 \mathrm{~d}$. Cows were managed according to herd standard operating procedures and housed either at the Marshfield Agricultural Research Station (MARS; Stratford, WI) or at the Emmons Blaine Arlington Dairy Research Center (ARL; Arlington, WI). A total of 54 cows were housed at the Marshfield location and 49 cows at the Arlington location. Pen capacities ranged from 32 to 90 cows depending on location. Far-off heifers (60-28 d before calving) were housed in confinement with freestalls bedded with sawdust or pressed manure solids. Close-up heifers ( $<28 \mathrm{~d}$ before calving) were housed in confinement with a deep straw-bedded pack. Lactating cows were housed in confinement with freestalls bedded with sand or pressed manure solids. The dry cow diet ingredient composition (\% of DM) at MARS was $32.9 \%$ corn silage, $30.6 \%$ alfalfa-grass silage, $9.0 \%$ wheat straw, and $27.5 \%$ protein-mineral mix with the formulated diet nutrient composition being $15.7 \% \mathrm{CP}, 36.2 \% \mathrm{NDF}$, and $1.49 \mathrm{Mcal}$ of $\mathrm{NE}_{\mathrm{L}} / \mathrm{kg}$ of DM. At ARL, the dry cow diet composition (\% of DM) was $48.6 \%$ corn silage, $29.6 \%$ wheat straw, and $21.8 \%$ protein-mineral mix with the formulated diet nutrient composition having $14.3 \%$ $\mathrm{CP}, 44 \% \mathrm{NDF}$, and $1.36 \mathrm{Mcal}$ of $\mathrm{NE}_{\mathrm{L}} / \mathrm{kg}$ of DM. The lactating cow diet composition (\% of DM) at MARS was $26.0 \%$ corn silage, $23.2 \%$ alfalfa/grass silage, $23.9 \%$ dry ground corn, $26.9 \%$ protein-mineral mix with the formulated diet nutrient composition being $17.2 \% \mathrm{CP}$, $28.6 \% \mathrm{NDF}$, and 1.71 Mcal of $\mathrm{NE}_{\mathrm{L}} / \mathrm{kg}$ of $\mathrm{DM}$. The lactation cow diet composition at ARL was $30.6 \%$ corn silage, $20.7 \%$ alfalfa silage, $12.2 \%$ high-moisture ground corn, $28.2 \%$ protein-mineral mix, $3.7 \%$ dry distillers grain, and $4.5 \%$ whole cottonseed with lint with the formulated diet nutrient composition being $16.8 \% \mathrm{CP}$, $29.4 \% \mathrm{NDF}$, and $1.67 \mathrm{Mcal}$ of $\mathrm{NE}_{\mathrm{L}} / \mathrm{kg}$ of DM. Cows were milked twice daily in either a double 8 herringbone parlor at MARS or a double 16 parallel parlor at ARL. Lactation records were obtained from herd management software (BoviSync; Bovisync LLC) for the first 150 DIM including calf BW, calving ease score, daily milk yield, and monthly milk composition data (fat and protein). Calving ease was scored on a scale of 1 to 5 with $1=$ no assistance, $2=$ slight problem, $3=$ needed some assistance, $4=$ considerable assistance needed, and $5=$ extreme difficulty. Animals that were culled or died before 150 DIM were not used in the lactation data analysis. A total of 103 heifers were included in the lactation data analysis (28 for low RFI fed LE; 22 for low RFI fed HE; 26 for high RFI fed LE; 29 for high RFI fed HE). Data were compiled into pen means before statistical analysis.

\section{Statistics}

All data were analyzed by PROC MIXED procedures of SAS (version 9.4; SAS Institute Inc.) as a randomized complete block design with 4 blocks and a $2 \times 2$ factorial arrangement of treatments ( 2 levels of RFI and 2 levels of diet energy), where pen served as the experimental unit. The model for the heifer data included RFI, diet, RFI $\times$ diet interaction, block, block $\times$ RFI interaction, and block $\times$ diet interaction as fixed effects. The model for the lactating cow data (except calf BW and calving ease score) included RFI, diet, RFI $\times$ diet interaction, block, block $\times$ RFI interaction, and block $x$ diet interaction as fixed effects. The lactating cow model included location to determine if the farm site affected production data (milk yield and components). Heifers were blocked deliberately on the basis of weight; therefore, block and block $\times$ treatment interactions were considered fixed variables, rather than random. Pen nested within treatment $(\mathrm{RFI} \times$ diet interaction) was considered a random effect. Least squares means were determined and treatment means compared when a significant interaction or significant main treatment effects were found. Statistical significance and trends 
were considered at $P \leq 0.05$ and $0.05<P \leq 0.10$, respectively.

\section{RESULTS AND DISCUSSION}

\section{Diet Formulation}

Ingredient and nutrient composition of the treatment diets and individual dietary components are presented in Table 1. Weekly analysis of experimental diets indicated that diets remained iso-nitrogenous (11.7 and $11.8 \%$ for LE and HE, respectively), with concentrations of $\mathrm{CP}$ varying minimally throughout the trial. The addition of straw led to a greater NDF concentration for LE (50.1\%) compared with HE (45.6\%). The use of straw to increase the dietary NDF carried the associated expectation that DMI would be reduced for heifers fed straw via the gut-fill mechanism. Coblentz et al. (2015) diluted corn-alfalfa silage diets with the addition of eastern gamagrass, corn fodder, or wheat straw and concluded that by diluting diets with lowquality forages, NDF in the diet was increased, thereby decreasing DMI. Furthermore, the inclusion of the diluents in the diet reduced energy content of the LE diet (57.0\% TDN and $2.18 \mathrm{Mcal}$ of $\mathrm{ME} / \mathrm{kg}$ ) compared with HE (62.7\% TDN and $2.39 \mathrm{Mcal}$ of ME $/ \mathrm{kg})$. The energy level for $\mathrm{HE}$ would be considered above requirements for heifers of this BW and days pregnant using NRC (2001) estimates for DMI and energy needs, and based on previous results in our freestall facility (Coblentz et al., 2015; Su et al., 2017; Li et al., 2019b). Current NRC (2001) DMI predictions for heifers are greater than expected based on these previous results in our facility, especially when feeding higher fiber diets than what we used in this study. It would be expected that a higher energy diet would be required with lower feed intakes to meet target growth rates, but we have found the energy concentration needed is similar to current NRC (2001) energy concentrations of about 57 to $60 \%$ TDN or $2.2 \mathrm{Mcal}$ of $\mathrm{ME} / \mathrm{kg}$ of DM when feeding high-fiber diets (50-55\% NDF, DM). Also, in freestall facilities the area available and the ability for heifers to exercise is more limited compared with animals in an open-lot facility, as the surfaces can be slippery and there is less area per animal for exercise (Fox and Tylutki, 1998). The research facility used in this study has smaller pens ( 8 heifers/pen; $84.5 \mathrm{~m}^{2} /$ pen including freestalls) with less space for heifers to move about the pen alleys than typical dairy operations. In addition, heifers in freestall facilities are exposed to less extreme weather conditions (cold and heat stress; rain, snow, and muddy conditions) than those in an open-lot facility, and thus may have lower maintenance energy requirements (Fox and Tylutki, 1998).

\section{Nutrient Intakes}

Nutrient intakes for heifers are presented in Table 2. The genomic RFI treatments did not affect DMI or nutrient intakes $(P \geq 0.11)$. This result differs from work by Williams et al. (2011) in which RFI was directly measured on dairy heifers and found that heifers ranking in the lowest 10\% RFI (more efficient) ate less feed than heifers ranking in the highest 10\% RFI (less efficient), while still having similar daily gains across both groups. However, feed intake can be similar for animals that may differ in efficiency with more efficient animals having greater growth, which was the case in the current study for the heifers fed the LE diet. The current study used genomic predictions for RFI and had less extreme differences between RFI groups (lowest or highest $50 \%$ ), which may also explain the differences between the studies.

The diet energy treatments had large effects on DMI and nutrient intakes. The increase in NDF in the LE diet reduced the DMI compared with HE (10.0 vs. 11.1 $\mathrm{kg} / \mathrm{d}$ for LE and HE, respectively; $P<0.01)$, with no effect of RFI $(P=0.44)$ or their interaction $(P=0.99)$ on intake. No difference in NDF intake was found across diet treatments $(P \geq 0.41)$ with a mean NDF intake of $5.0 \mathrm{~kg}$ of NDF/d. When calculated on a $\%$ of BW basis, NDF intake was close to $1 \%$ of BW $(0.95-0.99 \%$ of BW as NDF), which is consistent with the work by Hoffman et al. (2008) that found heifers eat approximately $1.0 \%$ of BW in NDF daily when offered high forage diets at ad libitum intakes. Several other studies with feeding higher fiber, lower energy diets for ad libitum intakes have also shown reduced intakes of DM and energy similar to our results (Greter et al., 2008; Coblentz et al., 2012, 2015; Su et al., 2017; Li et al., 2019b). Starch intake was greater $(P<0.01)$ for heifers fed the HE $\operatorname{diet}(1.7 \mathrm{~kg} / \mathrm{d})$ compared with the LE $\operatorname{diet}(1.1 \mathrm{~kg} / \mathrm{d})$, primarily because there was a greater amount of corn silage in the HE diet. Straw was effective as a dilutant forage to reduce the DMI and thus the TDN intake $(7.0$ vs. $5.7 \mathrm{~kg} / \mathrm{d}$ for $\mathrm{HE}$ and $\mathrm{LE}$, respectively; $P<$ 0.01). Similar responses were observed for $\mathrm{ME}, \mathrm{NE}_{\mathrm{G}}$, and $\mathrm{NE}_{\mathrm{M}}$ intakes $(P<0.01)$. Intakes of $\mathrm{CP}(1.31$ vs. $1.17 \mathrm{~kg} / \mathrm{d}), \mathrm{OM}$ (10.1 vs. $9.0 \mathrm{~kg} / \mathrm{d}$ ), fat (0.24 vs. 0.21 $\mathrm{kg} / \mathrm{d}), \mathrm{P}(29.8$ vs. $25.9 \mathrm{~g} / \mathrm{d})$, Ca (92.5 vs. $82.8 \mathrm{~g} / \mathrm{d}), \mathrm{K}$ (191.7 vs. $178.5 \mathrm{~g} / \mathrm{d})$, and $\mathrm{Mg}(27.6$ vs. $24.0 \mathrm{~g} / \mathrm{d})$ were all different $(P<0.01)$ between dietary treatments, with greater intakes observed for HE in all cases. These differences are a result of the decreased DMI for heifers fed LE as these components varied minimally between the 2 treatment diets.

The current study had lower DMI and energy intakes for both diet treatment groups (10 kg of DMI and 21.8 Mcal of ME for LE, and $11.1 \mathrm{~kg}$ of DMI and 26.4 Mcal 
of ME for HE) compared with $\mathrm{NRC}(2001)$ predicted energy requirements. The NRC (2001) predictions for a $520 \mathrm{~kg}$ of BW heifer (average of initial and final study weights) at $150 \mathrm{~d}$ pregnant were $12.7 \mathrm{~kg}$ of DMI, and 25.9 Mcal of ME for $0.9 \mathrm{~kg}$ of gain $/ \mathrm{d}$ and $29.6 \mathrm{Mcal}$ of ME for $1.17 \mathrm{~kg}$ of gain/d. As discussed previously, we have observed this in the freestall facility for previous studies (Coblentz et al., 2015; Su et al., 2017; Li et al., 2019b) and may be due to reduced energy use for exercise and reduced maintenance requirements in freestall or other confinement situations in which heifers have feed access and laying space in a small pen and have minimal environmental stress (Fox and Tylutki, 1998).

\section{Heifer Growth and Performance}

Heifer growth data are presented in Table 3. Initial body measurements were similar across treatment groups $(P>0.11)$; however, initial $\mathrm{BW}$ tended to be affected by RFI $(P=0.06)$ with the low and high RFI heifers having mean initial BW of 459.3 and $453.9 \mathrm{~kg}$, respectively. This tendency may have affected final BW data between RFI treatments with low and high RFI heifers having a mean final BW of 585.0 and $575.5 \mathrm{~kg}$, respectively, although the final $\mathrm{BW}$ was affected by a diet $\times$ RFI interaction $(P<0.01)$, whereas initial BW was not affected the treatment interaction $(P=0.43)$. However, this tendency is not likely to affect growth data in which the initial measures are subtracted from the final measures, or the feed efficiency data which uses the growth data and feed intake data.

Final BW was affected by diet $(P<0.01)$, RFI $(P$ $<0.01)$, and their interaction $(P<0.01)$. Heifers with either low or high RFI that were offered the HE diet did not differ $(P=0.63)$ in final BW (mean of $599 \mathrm{~kg}$ of BW) and exhibited the greatest final BW. In contrast, low RFI heifers offered the LE diet exhibited an intermediate final BW $(571 \mathrm{~kg})$, which was greater $(P$ $<0.01)$ than observed for the high RFI heifers offered the same diet $(553 \mathrm{~kg})$. Final heart girth was similar $(P=0.74)$ across RFI levels, but greater for heifers fed the HE diet than LE (201 vs. $196 \mathrm{~cm} ; P<0.01$ ), which follows the greater final BW for heifers offered the HE diet. Final hip height was similar across all treatments $(P>0.05)$ except for the high RFI heifers fed LE, who exhibited a shorter final hip height than the high RFI heifers fed HE $(P<0.01)$. Final rump fat thickness was affected by an interaction of RFI and diet $(P=0.02)$ with both RFI heifer groups fed the HE diet having the greatest fat thickness, the high RFI heifers fed LE being intermediate, and the low RFI heifers fed LE having the smallest rump fat thickness. The difference in rump fat thickness between low and high RFI heifers fed LE is similar to results from Herd et al. (2005) in which grazing Angus steers from low RFI lines had less rump and rib fat thickness compared with steers from high RFI lines. In addition, the researchers observed higher ADG and final weight for the low RFI steers during

Table 2. Nutrient intakes for heifers with different genomic predicted residual feed intake (RFI) and fed diets with different energy levels

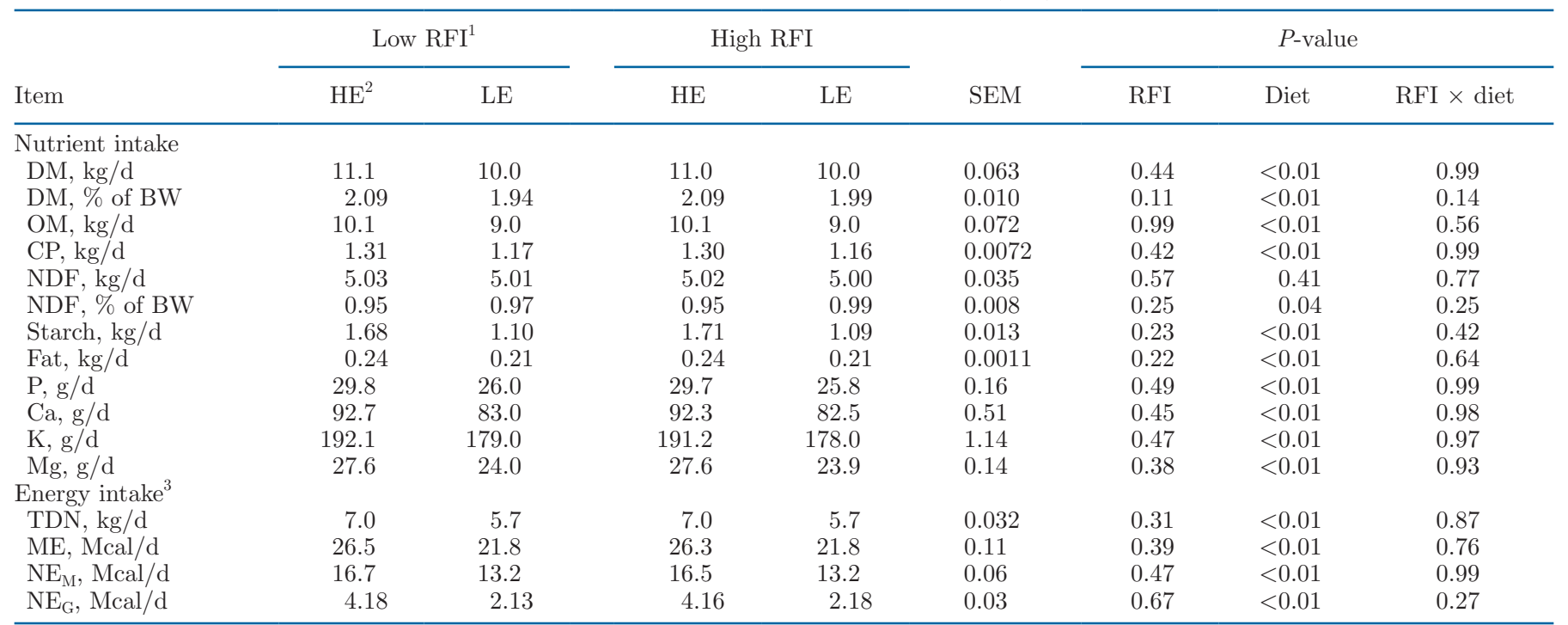

${ }^{1}$ Genomic predicted RFI; low $=$ predicted to have greater feed efficiency; high = predicted to have lower feed efficiency.

${ }^{2} \mathrm{HE}=$ diet with $52 \%$ alfalfa silage and $48 \%$ corn silage (DM basis) offered for ad libitum intake; LE = diet with $59.1 \%$ alfalfa silage, $26.8 \%$ corn silage, and $14.1 \%$ straw (DM basis) offered for ad libitum intake. $\mathrm{NE}_{\mathrm{G}}$ was calculated after accounting for DMI used for maintenance.

${ }^{3}$ Energy calculations based on NRC (2001). 
Table 3. Growth performance for Holstein dairy heifers with different genomic predicted residual feed intake (RFI) and fed diets with different energy levels

\begin{tabular}{|c|c|c|c|c|c|c|c|c|}
\hline Item & \multicolumn{2}{|c|}{ Low $^{1}$} & \multicolumn{2}{|c|}{ High } & SEM & \multicolumn{3}{|c|}{$P$-value } \\
\hline BW, kg & 460.3 & 458.2 & 456.7 & 451.1 & 4.04 & 0.06 & 0.13 & 0.43 \\
\hline Body length, cm & 152.3 & 151.0 & 151.9 & 152.0 & 0.43 & 0.79 & 0.60 & 0.57 \\
\hline Hip height, $\mathrm{cm}$ & 139.2 & 139.8 & 141.2 & 139.2 & 0.57 & 0.29 & 0.29 & 0.12 \\
\hline Heart girth, $\mathrm{cm}$ & 183.3 & 179.7 & 184.8 & 184.6 & 1.05 & 0.31 & 0.53 & 0.57 \\
\hline Kidney fat depth, cm & 14.6 & 14.3 & 14.8 & 15.2 & 0.26 & 0.13 & 0.95 & 0.28 \\
\hline \multicolumn{9}{|l|}{ Final } \\
\hline $\mathrm{BW}, \mathrm{kg}$ & $599.3^{\mathrm{a}}$ & $570.8^{\mathrm{b}}$ & $598.6^{\mathrm{a}}$ & $552.5^{\mathrm{c}}$ & 1.86 & $<0.01$ & $<0.01$ & $<0.01$ \\
\hline Body length, $\mathrm{cm}$ & 164.8 & 160.2 & 162.0 & 160.4 & 0.25 & 0.14 & 0.02 & 0.10 \\
\hline Hip height, cm & $142.4^{\mathrm{ab}}$ & $143.4^{\mathrm{ab}}$ & $144.5^{\mathrm{a}}$ & $141.7^{\mathrm{b}}$ & 0.55 & 0.68 & 0.21 & 0.04 \\
\hline Heart girth, $\mathrm{cm}$ & 201.4 & 196.4 & 201.4 & 196.1 & 0.21 & 0.74 & $<0.01$ & 0.74 \\
\hline BCS & 3.87 & 3.47 & 3.79 & 3.52 & 0.074 & 0.85 & 0.02 & 0.46 \\
\hline Body length, cm & 12.4 & 9.5 & 10.5 & 8.5 & 0.93 & 0.22 & 0.07 & 0.67 \\
\hline Hip height, cm & 3.5 & 3.6 & 3.7 & 2.7 & 0.32 & 0.36 & 0.29 & 0.19 \\
\hline Heart girth, $\mathrm{cm}$ & 18.1 & 16.8 & 16.6 & 11.5 & 1.17 & 0.34 & 0.36 & 0.57 \\
\hline $\mathrm{BCS}$ & 0.48 & 0.12 & 0.48 & 0.08 & 0.10 & 0.86 & 0.03 & 0.86 \\
\hline Rump fat depth, cm & $0.59^{\mathrm{a}}$ & $0.20^{\mathrm{c}}$ & $0.56^{\mathrm{a}}$ & $0.40^{\mathrm{b}}$ & 0.02 & 0.02 & $<0.01$ & 0.01 \\
\hline Kidney fat depth, $\mathrm{cm}$ & 1.39 & 1.50 & 1.70 & 1.12 & 0.52 & 0.95 & 0.68 & 0.55 \\
\hline Feed efficiency, $\mathrm{kg}$ of $\mathrm{DMI} / \mathrm{kg}$ of gain & $9.5^{\mathrm{c}}$ & $10.7^{\mathrm{b}}$ & $9.4^{\mathrm{c}}$ & $11.9^{\mathrm{a}}$ & 0.11 & 0.02 & $<0.01$ & $<0.01$ \\
\hline
\end{tabular}

${ }^{\mathrm{a}-\mathrm{c}}$ Least squares means within a row that have different superscripts differ $(P<0.05)$.

${ }^{1}$ Genomic predicted RFI: low $=$ predicted to have greater feed efficiency; high = predicted to have lower feed efficiency.

${ }^{2} \mathrm{HE}=$ diet with $52 \%$ alfalfa silage and $48 \%$ corn silage (DM basis) offered for ad libitum intake; LE = diet with $59.1 \%$ alfalfa silage, $26.8 \%$ corn silage, and $14.1 \%$ straw (DM basis) offered for ad libitum intake.

the growing phase, with these differences also persisting during the feedlot phase (Herd et al., 2003). Final BCS of heifers fed the HE diet was greater than heifers fed the LE $\operatorname{diet}(3.83$ vs. $3.50 ; P=0.02)$. The excess fat gain and condition for heifers fed $\mathrm{HE}$ can have negative consequences around calving such as increased calving difficulty (Hoffman et al., 1996). Recent work by Han et al. (2021) found that heifers which were heavier at first calving and likely with greater condition had greater first-lactation production, however, were culled from the herd at an earlier age due to greater negative energy balance and metabolic disease postcalving, and reduced reproduction.

These results confirm the validity of the ultrasound technique, as the rump fat depth followed closely the observed final BCS. Schröder and Staufenbiel (2006) observed a correlation between increased BCS and rump fat thickness with 1 BCS unit equating to approximately $1.0 \mathrm{~cm}$ of rump fat thickness. Based on the individual heifer data in the current study, BCS and rump fat thickness were also positively related to a 0.6 BCS unit increase equating to approximately 1.0 cm rump fat thickness. The use of ultrasound in conjunction with BCS may allow for more precision when evaluating body condition changes. The conventional BCS system may fail to detect slight changes in body condition (Ferguson et al., 1994), whereas ultrasound may be more sensitive to small changes in BCS over time.

Daily gain was affected by the interaction of RFI and $\operatorname{diet}(P=0.02)$ with low RFI heifers having greater gains than high RFI heifers when fed LE (0.94 vs. 0.85 $\mathrm{kg} / \mathrm{d} ; P=0.02$ ), but no difference was observed between RFI groups when the HE diet was offered (1.16 vs. 1.19 $\mathrm{kg} / \mathrm{d} ; P=0.25)$. Rump fat gain was also affected by an interaction of RFI and diet $(P=0.02)$, with heifers fed HE having greater gains than both RFI heifer groups fed LE; however, within the heifers fed the LE diet, the low RFI heifers had less rump fat gain $(P<0.01)$ than the high RFI heifers. This is possibly due to differential usage of nutrients between the RFI groups fed the LE diet, with low RFI heifers having less external fat deposition. No differences or interaction were observed for kidney fat gain between the treatments $(P>0.55)$. 
The heifers fed the LE diet had restricted growth and thus may have allowed for genomic RFI differences to become apparent compared with heifers fed the HE diet that had excessive growth. The HE diet led to higher growth rate that may have masked genomic RFI effects in this study. The differences in growth between RFI groups fed the LE diet may be caused by differences in nutrient utilization postabsorption, energy utilization, $\beta$-adrenergic receptors (Hardie et al., 2017), intake regulating hormones such as leptin (Hardie et al., 2017), or microbial populations and fermentation products (Carberry et al., 2012). Residual feed intake has been found to be highly polygenic with numerous genes possibly affecting feed intake, production, and efficiency (Hardie et al., 2017). Hardie et al. (2017) found 2 chromosome regions with genes that were highly related to RFI including a gene encoding for the $\beta-3$ adrenergic receptor that could affect utilization of energy and another gene encoding for the hormone leptin, which functions to regulate appetite and energy balance. Li et al. (2019a) also found several genes related to RFI with several affecting energy balance, feed intake, carbohydrate digestion and metabolism, protein synthesis, and immune response. Carberry et al. (2012) observed a relationship between RFI and rumen microbial population proportions when cattle were fed a high forage diet compared with a low forage diet. This suggests that the effect of RFI on rumen fermentation also may interact with diet composition. Our study did not evaluate rumen microbial population, ruminal nutrient digestibility, or fermentation products, but found an effect of RFI on daily gain when heifers were fed the LE diet with a greater NDF concentration. Numerous factors are involved with RFI and hence is difficult to draw specific conclusions about differences found in this study.

Although ADG was lower in heifers fed the LE diet, they were closer to desired growth targets for Holstein heifers with mature BW of 700 to $800 \mathrm{~kg}$ and first calving at $23 \mathrm{mo}$ of age $(0.8-1.0 \mathrm{~kg} / \mathrm{d}$; NRC, 2001). This suggests that heifers fed an energy-diluted diet more closely met energy requirements for targeted growth when fed for ad libitum intakes compared with a higher energy, lower fiber diet. The difference is mainly due to the lower energy content and reduced DMI when fed diets diluted with high-fiber, lower energy forages. When compared with the $\mathrm{NRC}(2001)$, the model underestimated the growth from available energy after maintenance for both treatments with heifers fed LE predicted to gain $0.50 \mathrm{~kg} / \mathrm{d}$ and heifers fed $\mathrm{HE}$ predicted to gain $1.0 \mathrm{~kg} / \mathrm{d}$ based on pen feed intakes, pen average BW, and diet energy contents. The difference between actual and predicted daily gains was greater for heifers fed LE, which may be due to greater than expect feed digestion and nutrient utilization at lower feed intakes; however, the total-tract NDF digestibilities were very similar to the in vitro NDF digestibility used for estimating energy concentrations. Another possible explanation is the maintenance energy estimate or the coefficients for predicting growth from available energy may need adjustment for current cattle genetics and management of heifers in confinement.

Feed efficiency was better for heifers fed the HE diets compared with the LE diet as expected (9.5 vs. 11.3 $\mathrm{kg}$ of DMI $/ \mathrm{kg}$ of gain; $P<0.01)$. However, feed efficiency was also affected $(P<0.01)$ by an interaction of RFI and diet with no difference between RFI levels for heifer fed HE (9.5 vs. $9.4 \mathrm{~kg} / \mathrm{kg}$ for low and high RFI, respectively, $P>0.10$ ), but was greater for heifers with low RFI compared with high RFI when offered the LE $\operatorname{diet}(10.7 \mathrm{vs} .11 .9 \mathrm{~kg}$ of $\mathrm{DMI} / \mathrm{kg}$ of gain; $P<0.01)$. The difference in feed efficiency between RFI groups when fed the LE diet but not the HE diet may be due to differences in utilization of the nutrients for growth with the HE diet being highly digestible with greater starch and energy content, which increased growth similarly for both LRFI and HRFI. The LE diet had higher fiber and lower energy content, which restricted energy intake and possibly allowed differences in digestion or energy utilization efficiency to become more apparent between RFI groups. These results indicate that the use of RFI to select for higher feed efficiency in lactating cattle could also result in increased feed efficiency for pregnant heifers when fed to achieve optimal growth targets at ad libitum intakes. The difference in intakes per unit of gain of approximately $1.2 \mathrm{~kg}$ of $\mathrm{DM} / \mathrm{kg}$ of gain is an increase of $11 \%$ more feed required for the high RFI heifers compared with low RFI heifers when fed the LE diet. Work by Williams et al. (2011) which measured RFI on dairy heifers showed significant differences in feed efficiency (1.7 $\mathrm{kg}$ of $\mathrm{DM} / \mathrm{kg}$ of gain) between the $10 \%$ most and least efficient heifers. The current study sorted the heifer population into the $50 \%$ highest or lowest genomically predicted RFI, which did not allow for the same extremes in predicted RFI between groups. However, we were still able to observe difference in feed efficiency between RFI groups. Previous work by our group (Williams et al., 2019) using a similar study design with prebreeding dairy heifers did not show differences in efficiency between different RFI groups fed a high or low energy diet. The differences between studies within the same herd may be due to changes in feed efficiency as animals approach mature BW with a greater portion of intake energy used for maintenance than for growth and possibly greater opportunity to improve feed efficiency. Further work to evaluate relationships of predicted RFI with actual feed 
efficiency, diet composition, and feeding management using individual heifer intakes would allow more direct relationships to be identified.

\section{Nutrient Digestibilities}

The mean nutrient intakes and digestibilities from wk 8 and 16 of the trial are presented in Table 4 . Similar to the overall study means, DMI was greater for heifers fed HE compared with LE (11.0 vs. 10.3 $\mathrm{kg} / \mathrm{d} ; P<0.01)$. Nitrogen intake was similar across RFI levels $(P=0.79)$, but was greater for heifers fed HE compared with LE $(1.40$ vs. $1.32 \mathrm{~kg} / \mathrm{d} ; P<0.01)$, which is attributed to the greater DMI for HE. The daily manure output of DM, OM, and NDF was less for heifers fed HE than that for the LE $(P=0.05)$, with no effect of RFI $(P \geq 0.86)$, or the interaction of RFI and diet $(P \geq 0.21)$. The lower DM, OM, and NDF manure outputs for heifers offered the HE diet was expected because this diet was more digestible, reducing the percentage of excretion for each component. However, manure output of $\mathrm{N}$ was similar across RFI levels and diet treatments $(P \geq 0.28)$ with no interaction of main effects $(P=0.21)$. Digestibilities of DM, $\mathrm{OM}, \mathrm{NDF}$, and apparent $\mathrm{N}$ were greater $(P \leq 0.04)$ for heifers offered HE compared with LE, but there were no differences in DM or nutrient digestibilities across RFI levels $(P \geq 0.76)$. Interestingly, the TMR in vitro 48-h NDF digestibilities measured in the laboratory
(54.2 and $50.2 \%$ in vitro NDF digestibility for HE and LE, respectively), had similar trends to the total-tract NDF digestibilities (58.8 and $49.8 \%$ total-tract NDF digestibility for HE and LE, respectively), and followed observed differences in total-tract estimates between the HE and LE diets. The differences in digestibilities between $\mathrm{HE}$ and $\mathrm{LE}$ were expected due to the difference in carbohydrate composition with $\mathrm{HE}$ having a higher starch content, which generally has greater digestibility than fibrous carbohydrates that were higher in LE. In addition, the in vitro NDF digestibility of the straw used in the LE diet was lower (39.2\% of NDF) than the haylage $(47.3 \%$ of NDF) or the corn silage $(60.2 \%$ of NDF) and thus caused the LE diet to have lower totaltract NDF digestion. Previous work by Coblentz et al. (2015) with heifers fed either a control diet (corn silage and alfalfa silage) or diets diluted with higher fiber forages also found improved digestibilities for heifers fed the control diet that contained greater starch and lower fiber concentrations.

\section{Lactation Performance}

Calf BW, daily milk yields, fat percent, and protein percent are found in Table 5. Calf BW, calving ease, milk yield, and milk components were not affected by RFI, diet, or their interaction $(P \geq 0.09)$. Calf BW and calving ease score was affected by research location with heifers calving at the MARS location having greater

Table 4. Digestibilities of various nutrients by dairy heifers with different genomic residual feed intake (RFI) and fed diets with different energy levels

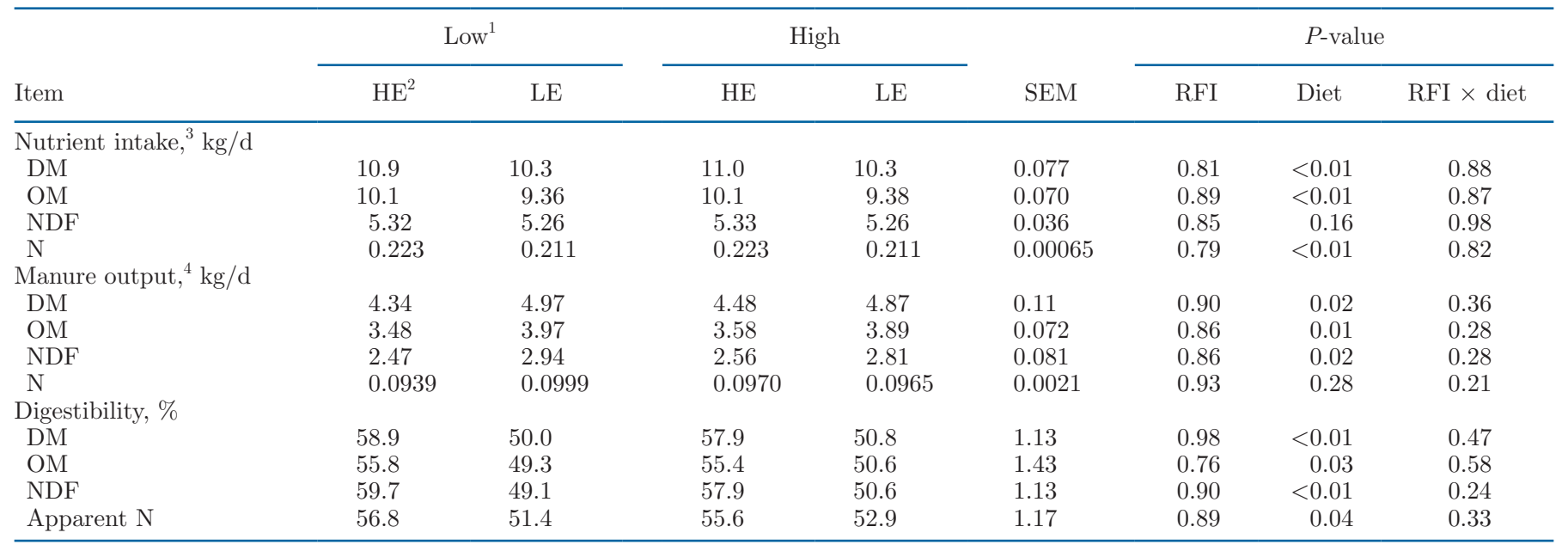

${ }^{1}$ Genomic predicted RFI: low = predicted to have greater feed efficiency; high = predicted to have lower feed efficiency.

${ }^{2} \mathrm{HE}=$ diet with $52 \%$ alfalfa silage and $48 \%$ corn silage (DM basis) offered for ad libitum intake; LE = diet with $59.1 \%$ alfalfa silage, $26.8 \%$ corn silage, and $14.1 \%$ straw (DM basis) offered for ad libitum intake.

${ }^{3}$ Based on wk 8 and 16 of trial. All calculations were based on collective DMI and orts for the entire week of analysis, then reported on a daily per heifer basis.

${ }^{4}$ Whole-pen manure was collected on wk 8 and 16 after the 48-h collection period and data were averaged across both periods with manure output per heifer reported. 
Table 5. Milk yield and milk components in the first $150 \mathrm{~d}$ of lactation for dairy heifers with different genomic predicted residual feed intake (RFI) and fed diets with different energy levels as postbred heifers

\begin{tabular}{|c|c|c|c|c|c|c|c|c|}
\hline Item & \multicolumn{2}{|c|}{ Low $^{1}$} & \multicolumn{2}{|c|}{ High } & SEM & \multicolumn{3}{|c|}{$P$-value } \\
\hline Milk yield,${ }^{4} \mathrm{~kg} / \mathrm{d}$ & 38.7 & 37.8 & 38.1 & 37.3 & 2.13 & 0.61 & 0.44 & 0.95 \\
\hline Fat, ${ }^{5} \%$ & 3.99 & 3.83 & 3.88 & 4.20 & 0.097 & 0.27 & 0.50 & 0.09 \\
\hline Protein, ${ }^{5} \%$ & 2.97 & 2.90 & 2.93 & 2.98 & 0.037 & 0.59 & 0.75 & 0.13 \\
\hline
\end{tabular}

${ }^{1}$ Genomic predicted RFI: low = predicted to have greater feed efficiency; high = predicted to have lower feed efficiency.

${ }^{2} \mathrm{HE}=$ diet with $52 \%$ alfalfa silage and $48 \%$ corn silage (DM basis) offered for ad libitum intake; LE = diet with $59.1 \%$ alfalfa silage, $26.8 \%$ corn silage, and $14.1 \%$ straw (DM basis) offered for ad libitum intake.

${ }^{3}$ Calving ease scored using a scale of 1 to 5 with $1=$ no assistance, $2=$ slight problem, $3=$ needed some assistance, $4=$ considerable assistance needed, and $5=$ extreme difficulty.

${ }^{4}$ Milk yield average for each animal was obtained daily for $150 \mathrm{~d}$. Average milk yield was calculated by averaging yield for animals within each treatment pen. Animals per treatment with 150 d lactation data: 28 for low RFI fed LE; 22 for low RFI fed HE; 26 for high RFI fed LE; 29 for high RFI fed HE.

${ }^{5}$ Fat and protein content tested monthly. Averages were then calculated for the first $150 \mathrm{~d}$.

mean calf BW (38.5 vs. $34.0 \mathrm{~kg})$ and calving ease score (1.46 vs. $1.02 ; P<0.01)$ than heifers calving at the ARL location $(P<0.01)$. This difference between locations is likely due to herd management such that heifers calving at MARS were primarily carrying bull calves, while heifers calving at ARL were primarily carrying heifer calves as this is the rearing location of preweaning replacement heifer calves. The lack of effect of diet energy level fed to postbred heifers on first-lactation performance should be considered with caution as the heifers fed HE had excessive body condition at the end of the study (BCS of 3.8-3.9). Excessive condition has been associated with increased dystocia at first parturition (Hoffman et al., 1996) and could be detrimental to cow and calf health; however, no difference in calving ease was observed in the current study. All the animals in the current study were bred according to herd standard procedures with first breeding occurring at approximately 13 mo of age and when heifers weigh at least $375 \mathrm{~kg}$ to ensure heifers are adequate size. Work by Hoffman et al. (1996) separated heifers that were fed a control or accelerated growth diet into groups having either a targeted breeding (bred within $21 \mathrm{~d}$ after treatment initiation and confirmed pregnant after 1 insemination) or a delayed breeding schedule (not observed in estrus with $21 \mathrm{~d}$ or requiring more than 1 insemination for conception). Hoffman et al. (1996) found that heifers in the target breeding group became pregnant and calved earlier, and also had lower BCS at calving and lower calving ease scores. Delayed breeding or poor conception allowed heifers to gain additional weight and condition before calving; thus, the reproduction and nutrition programs both play important roles in heifer management. In addition, a study by Han et al. (2021) found that heifers with higher BW
$(>570 \mathrm{~kg})$ and maturity rate $(>80 \%$ of mature $\mathrm{BW}$ at first calving) after first calving had somewhat higher first-lactation milk yields, but did not have greater milk yield through the first 24 mo after first calving. Heavier first-lactation cows also had greater BW loss during the first month of lactation, greater culling risks, and less longevity. The authors concluded that the greater BW at first calving predisposed cows to excessive body condition mobilization and negative energy balance, which negatively affected reproduction and longevity in the herd. Additional research is needed to evaluate current suggested targets for heifer BCS before calving (3.5) as suggested BCS targets for lactating cows is trending lower (2.5-3) based upon recent transition cow and reproduction work revealing cows with a moderate BCS at calving are able to better maintain or gain condition in early lactation and subsequently have improved reproduction (Carvalho et al., 2014; Barletta et al., 2017; Middleton et al., 2019).

Calf BW were not different across treatments in the current study and indicates adequate fetal nutrition. The current study was only conducted up to 60 d prepartum and may have had a limited effect on the last trimester of fetal growth in which approximately $75 \%$ of fetal growth occurs (Swett et al., 1948; House and Bell, 1993). Hoffman et al. (1996) also found no difference in calf $\mathrm{BW}$ for postpubertal dairy heifers fed either accelerated growth diets (69\% TDN, DM) or controlled growth diets (62\% TDN, DM). Ketosis treatment incidence (raw incidence rate) was variable with 10.7 and $24 \%$ of low and high RFI heifers fed LE treated, respectively, and 23.8 and $20.7 \%$ of low and high RFI heifers fed HE treated, respectively.

It is not surprising we did not find differences in lactation performance between RFI groups due to the 
RFI trait considered independent of production traits. Work by Macdonald et al. (2014) in which heifers with divergent RFI were followed through first lactation also found no difference in feed intake, milk production, or component production between the low and high RFI heifers. Even without differences in production, Macdonald et al. (2014) still found that the cows with a low RFI measured while a heifer had improved feed efficiency compared with cows with a high RFI measured while a heifer. However, feed intake was not measured during first lactation in the current study and thus feed efficiency could not be calculated.

\section{CONCLUSIONS}

Dairy heifers fed an alfalfa-corn silage diet diluted with straw had decreased DMI and energy consumption, while having more desirable weight gain and body condition compared with heifers fed the undiluted diet with lower fiber and higher energy concentrations. Feed efficiency of heifers with different RFI was dependent on diet energy level, with low RFI heifers using the moderate energy straw diet more efficiently. Feeding bred and pregnant heifers a high energy diet resulted in excessive weight and condition gains; however, this did not negatively affect first-lactation performance.

\section{ACKNOWLEDGMENTS}

The authors thank the staff at University of Wisconsin Marshfield Agricultural Research Station and the USDA Dairy Forage Research Center for their assistance in completing this project. Mention of trade names or commercial products in this article is solely for the purpose of providing specific information, and does not imply either recommendation or endorsement by the USDA. The USDA is an equal opportunity provider and employer. This work was supported (in part) by a Non-Assistance Cooperative Agreement (\#58-36554-052) from the USDA-Agricultural Research Service (Washington, DC). The authors have not stated any conflicts of interest.

\section{REFERENCES}

Akins, M. S., L. M. Vanderwerff, M. A. Hagedorn, P. C. Hoffman, S. L. Gunderson, and T. L. Kohlman. 2015. Economic costs and labor efficiencies associated with raising dairy herd replacements on Wisconsin Dairy Farms and Custom Heifer Raising Operations. Accessed May 25, 2021. https://fyi.extension.wisc.edu/ heifermgmt/files/2015/02/ICPA-2013-v4.pdf.

AOAC. 1990. Official Methods of Analysis. 15th ed. Association of Official Analytical Chemists.

AOAC International. 1998. Official Methods of Analysis. 16th ed. AOAC International.

Barletta, R. V., M. Maturana Filho, P. D. Carvalho, T. A. Del Valle, A. S. Netto, F. P. Rennó, R. D. Mingoti, J. R. Gandra, G. B. Mourão,
P. M. Fricke, R. Sartori, E. H. Madureira, and M. C. Wiltbank. 2017. Association of changes among body condition score during the transition period with NEFA and BHBA concentrations, milk production, fertility, and health of Holstein cows. Theriogenology 104:30-36. https://doi.org/10.1016/j.theriogenology.2017.07.030.

Berry, D. P., M. P. Coffey, J. E. Pryce, Y. de Haas, P. Lovendahl, N. Krattenmacher, J. J. Crowley, Z. Wang, D. Spurlock, K. Weigel, K. Macdonald, and R. F. Veerkamp. 2014. International genetic evaluations for feed intake in dairy cattle through the collation of data from multiple sources. J. Dairy Sci. 97:3894-3905. https://doi .org $/ 10.3168 / j d s .2013-7548$.

Carberry, C. A., D. A. Kenny, S. Han, M. S. McCabe, and S. M. Waters. 2012. Effect of phenotypic residual feed intake and dietary forage content on the rumen microbial community of beef cattle. Appl. Environ. Microbiol. 78:4949-4958. https://doi.org/10.1128/ AEM.07759-11.

Carvalho, P. D., A. H. Souza, M. C. Amundson, K. S. Hackbart, M. J. Fuenzalida, M. M. Herlihy, H. Ayres, A. R. Dresch, L. M. Vieira, J. N. Guenther, R. R. Grummer, P. M. Fricke, R. D. Shaver, and M. C. Wiltbank. 2014. Relationships between fertility and postpartum changes in body condition and body weight in lactating dairy cows. J. Dairy Sci. 97:3666-3683. https://doi.org/10.3168/ jds.2013-7809

Coblentz, W. K., N. M. Esser, P. C. Hoffman, and M. S. Akins. 2015. Growth performance and sorting characteristics of corn silagealfalfa haylage diets with or without forage dilution offered to replacement Holstein dairy heifers. J. Dairy Sci. 98:8018-8034. https://doi.org/10.3168/jds.2015-9491.

Coblentz, W. K., P. C. Hoffman, N. M. Esser, and M. G. Bertram. 2012. Using eastern gamagrass to construct diets that limit intake and caloric density for dairy replacement heifers. J. Dairy Sci. 95:6057-6071. https://doi.org/10.3168/jds.2012-5686.

Coblentz, W. K., P. C. Hoffman, N. M. Esser, and M. G. Bertram. 2013. Technical note: Whole-pen assessments of nutrient excretion and digestibility from dairy replacement heifers housed in sandbedded freestalls. J. Anim. Sci. 91:4841-4848. https://doi.org/10 $.2527 /$ jas.2012-6168.

de Haas, Y., J. E. Pryce, M. P. L. Calus, E. Wall, D. P. Berry, P. Lovendahl, N. Krattenmacher, F. Miglior, K. Weigel, D. Spurlock, K. A. Macdonald, B. Hulsegge, and R. F. Veerkamp. 2015. Genomic prediction of dry matter intake in dairy cattle from an international data set consisting of research herds in Europe, North American, and Australasia. J. Dairy Sci. 98:6522-6534. https:// doi.org/10.3168/jds.2014-9257.

Ferguson, J. D., D. T. Galligan, and N. Thomsen. 1994. Principal descriptors of body condition score in Holstein cows. J. Dairy Sci. 77:2695-2703. https://doi.org/10.3168/jds.S0022-0302(94)77212 $-X$.

Fox, D. G., and T. P. Tylutki. 1998. Accounting for the effects of environment on the nutrient requirements of dairy cattle. J. Dairy Sci. 81:3085-3095. https://doi.org/10.3168/jds.S0022-0302(98)75873 -4 .

Goering, H. K., and P. J. Van Soest. 1970. Pages 8-11 in Forage Fiber Analyses (Apparatus, Reagents, Procedures, and Some Applications). Agric. Handbook No. 379. USDA-ARS.

Greter, A. M., T. J. DeVries, and M. A. G. von Keyserlingk. 2008. Nutrient intake and feeding behavior of growing dairy heifers: Effects of dietary dilution. J. Dairy Sci. 91:2786-2795. https://doi.org/10 $.3168 /$ jds.2008-1052.

Greter, A. M., B. L. Kitts, and T. J. DeVries. 2011. Short communication: Limit feeding dairy heifers: Effect of feed bunk space and provision of a low-nutritive feedstuff. J. Dairy Sci. 94:3124-3129. https://doi.org/10.3168/jds.2010-4029.

Han, L., A. J. Heinrichs, A. De Vries, and C. D. Dechow. 2021. Relationship of body weight at first calving with milk yield and herd life. J. Dairy Sci. 104:397-404. https://doi.org/10.3168/jds.2020 $-19214$.

Hardie, L. C., M. J. VandeHaar, R. J. Tempelman, K. A. Weigel, L. E. Armentano, G. R. Wiggans, R. F. Veerkamp, Y. de Haas, M. P. Coffey, E. E. Connor, M. D. Hanigan, C. Staples, Z. Wang, J. C. M. Dekkers, and D. M. Spurlock. 2017. The genetic and biologi- 
cal basis of feed efficiency in mid-lactation Holstein dairy cows. J. Dairy Sci. 100:9061-9075. https://doi.org/10.3168/jds.2017-12604.

Herd, R. M., J. A. Archer, and P. F. Arthur. 2003. Selection for low postweaning residual feed intake improves feed efficiency of steers in feedlot. Proc. Assoc. Adv. Anim. Breed. Gen. 15:310-313.

Herd, R. M., P. F. Arthur, and J. A. Archer. 2005. When pastures limit growth rate of steers those bred for low residual feed intake grow faster. Proc. Assoc. Adv. Anim. Breed. Gen. 16:330-333.

Hoffman, P. C., N. M. Brehm, S. G. Price, and A. Prill-Adams. 1996. Effect of accelerated postpubertal growth and early calving on lactation performance of primiparous Holstein heifers. J. Dairy Sci. 79:2024-2031. https://doi.org/10.3168/jds.S0022-0302(96)76575 $-\mathrm{X}$.

Hoffman, P. C., C. R. Simson, and M. Wattiaux. 2007. Limit feeding of gravid Holstein heifers: Effect on growth, manure nutrient excretion, and subsequent early lactation performance. J. Dairy Sci. 90:946-954. https://doi.org/10.3168/jds.S0022-0302(07)71578-3.

Hoffman, P. C., K. A. Weigel, and R. M. Wernberg. 2008. Evaluation of equations to predict dry matter intake of dairy heifers. J. Dairy Sci. 91:3699-3709. https://doi.org/10.3168/jds.2007-0644.

House, W. A., and A. W. Bell. 1993. Mineral accretion in the fetus and adnexa during late gestation in Holstein cows. J. Dairy Sci. 76:2999-3010. https://doi.org/10.3168/jds.S0022-0302(93)77639 $-0$.

Koch, R. M., L. A. Swiger, D. Chambers, and K. E. Gregory. 1963. Efficiency of feed use in beef cattle. J. Anim. Sci. 22:486-494. https: //doi.org/10.2527/jas1963.222486x.

Kruse, K. A., D. K. Combs, N. M. Esser, W. K. Coblentz, and P. C. Hoffman. 2010. Evaluation of potential carryover effects associated with limit feeding of gravid Holstein heifers. J. Dairy Sci. 93:5374-5384. https://doi.org/10.3168/jds.2010-3401.

Li, B., L. Fang, D. J. Null, J. L. Hutchison, E. E. Connor, P. M. VanRaden, M. J. VandeHaar, R. J. Tempelman, K. A. Weigel, and J. B. Cole. 2019a. High-density genome-wide association study for residual feed intake in Holstein dairy cattle. J. Dairy Sci. 102:1106711080. https://doi.org/10.3168/jds.2019-16645.

Li, L., N. M. Esser, R. K. Ogden, W. K. Coblentz, and M. S. Akins. 2019b. Comparison of feeding diets diluted with sorghum-sudangrass silage or low-quality grass on nutrient intake and digestibility and growth performance of Holstein dairy heifers. J. Dairy Sci. 102:9932-9942. https://doi.org/10.3168/jds.2018-16168.

Macdonald, K. A., J. E. Pryce, R. J. Spelman, S. R. Davis, W. J. Wales, G. C. Waghorn, Y. J. Williams, L. C. Marett, and B. J. Hayes. 2014. Holstein-Friesian calves selected for divergence in residual feed intake during growth exhibited significant but reduced residual feed intake divergence in their first lactation. J. Dairy Sci. 97:1427-1435. https://doi.org/10.3168/jds.2013-7227.

Middleton, E. L., T. Minela, and J. R. Pursley. 2019. The high-fertility cycle: How timely pregnancies in one lactation may lead to less body condition loss, fewer health issues, greater fertility, and reduced early pregnancy losses in the next lactation. J. Dairy Sci. 102:5577-5587. https://doi.org/10.3168/jds.2018-15828.

NRC. 2001. Nutrient Requirements of Dairy Cattle. 7th rev. ed. National Academies Press.

Pryce, J. E., J. Arias, P. J. Bowman, S. R. Davis, K. A. Macdonald, G. C. Waghorn, W. J. Wales, Y. J. Williams, R. J. Spelman, and B. J. Hayes. 2012. Accuracy of genomic predictions of residual feed intake and 250-day body weight in growing heifers using 625,000 single nucleotide polymorphism markers. J. Dairy Sci. 95:21082119. https://doi.org/10.3168/jds.2011-4628.

Pryce, J. E., O. Gonzalez-Recio, G. Nieuwhof, W. J. Wales, M. P. Coffey, B. J. Hayes, and M. E. Goddard. 2015. Hot topic: Definition and implementation of a breeding value for feed efficiency in dairy cows. J. Dairy Sci. 98:7340-7350. https://doi.org/10.3168/ jds.2015-9621.

Ribeiro, F. R. B., L. O. Tedeschi, J. R. Stouffer, and G. E. Carstens. 2008. Technical note: A novel technique to assess internal body fat of cattle by using real -time ultrasound. J. Anim. Sci. 86:763-767. https://doi.org/10.2527/jas.2007-0560.

Schröder, U. J., and R. Staufenbiel. 2006. Invited review: Methods to determine body fat reserves in the dairy cow with special regard to ultrasonographic measurement of backfat thickness. J. Dairy Sci. 89:1-14. https://doi.org/10.3168/jds.S0022-0302(06)72064-1.

Schulte, E. E., J. B. Peters, and P. R. Hodgson. 1987. Wisconsin procedures for soil testing, plan analysis, and feed and forage analysis. Dept. Soil Sci. Bull. No. 6. University of Wisconsin, Madison.

St-Pierre, N. R. 2007. Design and analysis of pen studies in the animal sciences. J. Dairy Sci. 90(E. Suppl.):E87-E89.

Su, H., M. S. Akins, N. M. Esser, R. Ogden, W. K. Coblentz, K. F. Kalscheur, and R. Hatfield. 2017. Effects of feeding alfalfa stemlage or wheat straw for dietary energy dilution on nutrient intake and digestibility, growth performance, and feeding behavior of Holstein dairy heifers. J. Dairy Sci. 100:7106-7115. https://doi.org/10 .3168/jds.2016-12448.

Swett, W. W., C. A. Matthews, and M. H. Fohrman. 1948. Development of the fetus in the dairy cow. No. 170289. US Department of Agriculture, Technical Bulletin no. 964.

Tempelman, R. J., D. M. Spurlock, M. Coffey, R. F. Veerkamp, L. E. Armentano, K. A. Weigel, Y. de Haas, C. R. Staples, E. E. Connor, Y. Lu, and M. J. VandeHaar. 2015. Heterogeneity in genetic and non-genetic variation and energy sink relationships for residual feed intake across research stations and countries. J. Dairy Sci. 98:2013-2026. https://doi.org/10.3168/jds.2014.8510.

Vallimont, J. E., C. D. Dechow, J. M. Daubert, M. W. Dekleva, J. W. Blum, C. M. Barlieb, W. Liu, G. A. Varga, A. J. Heinrichs, and C. R. Baumrucker. 2011. Short communication: Heritability of gross feed efficiency and association with yield, intake, residual intake, body weight, and body condition score in 11 commercial Pennsylvania tie stalls. J. Dairy Sci. 94:2108-2113. https://doi.org/10 $.3168 /$ jds.2010-3888.

Wildman, E. E., G. M. Jones, P. E. Wagner, R. L. Boman, H. F. Trout Jr., and T. N. Lesch. 1982. A dairy cow body condition scoring system and its relationship to selected production characteristics. J. Dairy Sci. 65:495-501. https://doi.org/10.3168/jds .S0022-0302(82)82223-6.

Williams, K. T., K. A. Weigel, W. K. Coblentz, N. M. Esser, H. Schlesser, P. C. Hoffman, H. Su, and M. S. Akins. 2019. Effect of diet energy density and genomic residual feed intake on prebred dairy heifer feed efficiency, growth, and manure excretion. J. Dairy Sci. 102:4041-4050. https://doi.org/10.3168/jds.2018-15504.

Williams, Y. J., J. E. Pryce, C. Grainger, W. J. Wales, N. Linden, M. Porker, and B. J. Hayes. 2011. Variation in residual feed intake in Holstein-Friesian dairy heifers in southern Australia. J. Dairy Sci. 94:4715-4725. https://doi.org/10.3168/jds.2010-4015.

\section{ORCIDS}

K. T. Williams @ \ttps://orcid.org/0000-0001-8233-4693

K. A. Weigel $\odot$ https://orcid.org/0000-0002-2391-6260

W. K. Coblentz @ https://orcid.org/0000-0003-2477-3449

N. M. Esser (® https://orcid.org/0000-0003-2021-691X

R. Ogden ๑ https://orcid.org/0000-0003-0337-0253

H. Su ๑ https://orcid.org/0000-0001-9934-9576

M. S. Akins (i) https://orcid.org/0000-0001-5517-1681 